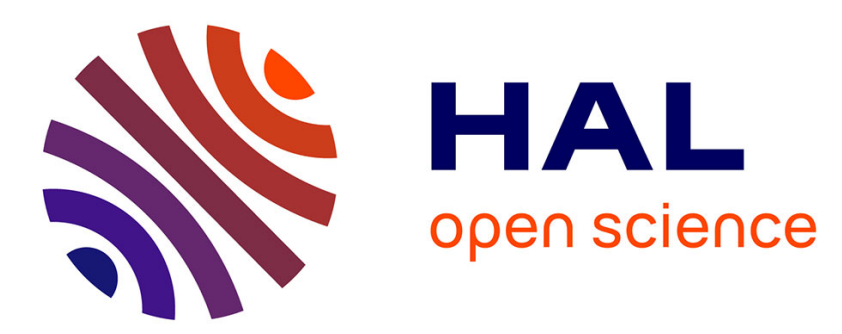

\title{
Expanding Photovoltaic Penetration with Residential Distributed Generation from Hybrid Solar Photovoltaic. Combined Heat and Power Systems \\ Joshua Pearce
}

\section{- To cite this version: \\ Joshua Pearce. Expanding Photovoltaic Penetration with Residential Distributed Generation from Hybrid Solar Photovoltaic. Combined Heat and Power Systems. Energy, 2009, 34, pp.1947-1954. 10.1016/j.energy.2009.08.012 . hal-00677851}

\section{HAL Id: hal-00677851 \\ https://hal.science/hal-00677851}

Submitted on 9 Mar 2012

HAL is a multi-disciplinary open access archive for the deposit and dissemination of scientific research documents, whether they are published or not. The documents may come from teaching and research institutions in France or abroad, or from public or private research centers.
L'archive ouverte pluridisciplinaire HAL, est destinée au dépôt et à la diffusion de documents scientifiques de niveau recherche, publiés ou non, émanant des établissements d'enseignement et de recherche français ou étrangers, des laboratoires publics ou privés. 
Published: J. M. Pearce, "Expanding Photovoltaic Penetration with Residential Distributed Generation from Hybrid Solar Photovoltaic + Combined Heat and Power Systems", Energy 34, pp. 1947-1954 (2009). http://dx.doi.org/10.1016/j.energy.2009.08.012

\title{
Expanding Photovoltaic Penetration with Residential Distributed Generation from Hybrid Solar Photovoltaic and Combined Heat and Power Systems
}

\author{
J. M. Pearce* \\ Department of Mechanical and Materials Engineering, Queen's University, 60 Union Street, \\ Kingston, ON Canada
}

\begin{abstract}
The recent development of small scale combined heat and power (CHP) systems has provided the opportunity for in-house power backup of residential-scale photovoltaic (PV) arrays. This paper investigates the potential of deploying a distributed network of PV+CHP hybrid systems in order increase the PV penetration level in the U.S. The temporal distribution of solar flux, electrical and heating requirements for representative U.S. single family residences were analyzed and the results clearly show that hybridizing CHP with PV can enable additional PV deployment above what is possible with a conventional centralized electric generation system. The technical evolution of such PV+CHP hybrid systems was developed from the present (near market) technology through four generations, which enable high utilization rates of both PV-generated electricity and CHP-generated heat. A method to determine the maximum percent of PV-generated electricity on the grid without energy storage was derived and applied to an example area. The results show that a PV+CHP hybrid system not only has the potential to radically reduce energy waste in the status quo electrical and heating systems, but it also enables the share of solar PV to be expanded by about a factor of five.
\end{abstract}

\section{Introduction}

Photovoltaic (PV) technology, which converts sunlight directly into electricity, provides a technologically feasible solution to the current environmental challenges created by current reliance on fossil fuel-based electrical power generation [1]. PV energy production, which is a large net energy producer and thus $\mathrm{CO}_{2}$ emission reducer, represents an environmentally beneficial and sustainable method of maintaining an energy intensive standard of living [2-5]. PV, however, has had extremely limited deployment, making up far less than one percent of the global electricity generation [6] due primarily to economics. The costs of PV-generated electricity are expected to decline as production continues to climb and benefits from economies of scale; and supply finally catches up with demand [79]. As the world's politicians better understand the threat posed by climate destabilization outlined by the IPCC it is likely that more countries will levy additional charges on electricity generation that reflect the costs of environmental damages not only from local pollutants $\left(\mathrm{SO}_{2}, \mathrm{NO}_{\mathrm{x}}\right)$, wastes, occupational health, risk of accidents, noise and other burdens, but also climate change via carbon taxes [10]. It has been shown that the policies internalizing external cost only to the power sector, are unlikely to be sufficient to reduce global carbon emissions to levels needed for $550 \mathrm{ppmv}$ target, so that the efforts to curb GHG emissions will have to be further accelerated in the latter half of the $21^{\text {st }}$ century [11]. However, taxing GHG emissions will not only lead to energy conservation, but it will also improve the economic competitiveness of PV, which makes the limiting factors of PV deployment solely technical.

\footnotetext{
"Corresponding author: pearce@ me.queensu.ca phone 613-533-3369 fax 613-533-6610
} 
Published: J. M. Pearce, "Expanding Photovoltaic Penetration with Residential Distributed Generation from Hybrid Solar Photovoltaic + Combined Heat and Power Systems", Energy 34, pp. 1947-1954 (2009). http://dx.doi.org/10.1016/j.energy.2009.08.012

The primary technical limitation of the penetration level of PV is the inherent intermittency, which makes deploying PV alone unable to fully replace a new power plant operated in base load. Therefore, following a conventional centralized grid model, the load of other units (including less efficient and more polluting coal units) must increase, which is unfavorable for both the primary energy savings and the GHG emission reduction viewpoints. The solar electricity percentage, or penetration level, can be increased favorably if either the grid is altered, large scale storage is implemented, or if PV is hybridized with other electricity-generating or storage technologies that can provide electrical power during the night primarily and secondarily during cloudy weather with short response times.

This paper explores one method of increasing the PV penetration level when technical criteria alone are used to determine deployment. Specifically this paper investigates the potential of supplementing distributed solar photovoltaic generation with electricity from residential combined heat and power (CHP) systems to form a distributed network of PV+CHP hybrid systems in order increase the PV penetration level in the U.S. First, the challenges of the conventional centralized utility grid will be summarized along with the advantages of shifting to a more distributed generation (DG) system. Then the technical limitations of using PV as the source of DG will be reviewed for determining the PV penetration limits in a conventional grid design. Next, the electrical and heating requirements for representative U.S. single family residences will be analyzed to determine the viability of creating a distributed network of PV systems hybridized to small scale CHP units. Then the technical evolution of such PV+CHP hybrid systems will be planned through four generations. Next the sizing of $\mathrm{PV}+\mathrm{CHP}$ systems will be explored and a method to determine the maximum percent of PV-generated electricity on the grid without energy storage will be will be derived. This method will be used to determine the maximum percent PV increase on the grid made possible in an example location and conclusions will be drawn about the technical viability of PV+CHP hybrids used in single family residences.

\section{Technical Limits to PV Penetration in the Current Grid}

Technical inertia and poor planning have resulted in an aging power infrastructure in the U.S. with an urgent need for modernization of the electric system [12,13]. Growth in electricity demand and new generation, lack of investment in new transmission facilities, and the incomplete transition to fully efficient and competitive wholesale markets have allowed transmission bottlenecks to emerge [14]. Transmission bottlenecks have several negative drawbacks most notably decreasing reliability, which increases the risks of blackouts, and can be viewed as a national security issue and a considerable economic problem as they also increase electricity costs to consumers overall [15]. This problem is compounded by such factors as difficulty in obtaining rights-of-way, the strong environmental movement - particularly of the NIMBY-variety and public protest against the construction of additional transmission facilities, and the resulting inability to expand the constrained system [16].

Solar PV offers a technical solution to reduce some of the pressure on the nation's transmission infrastructure. In particular it can be part of the solution to deliver firm, dependable power during extreme peak conditions leading to outage situations [17]. Solar photovoltaic electric production has the advantage over more conventional forms of electricity supply of being an inherently distributed energy source. Solar photovoltaic systems can often be located near the consumer and thus decrease transmission losses by placing solar panels on any surface that is exposed to sunlight without large shading losses during the day. Solar PV is thus one of the most promising technologies to offer a large 
Published: J. M. Pearce, "Expanding Photovoltaic Penetration with Residential Distributed Generation from Hybrid Solar Photovoltaic + Combined Heat and Power Systems”, Energy 34, pp. 1947-1954 (2009). http://dx.doi.org/10.1016/j.energy.2009.08.012

scale distributed alternative generation supply to offset GHG emissions while relieving stress on the grid. Such distributed generation (DG) networks act like peer-to-peer file sharing systems like bit torrent on the modern internet rather than the primitive internet and conventional grid with few centers of information and energy, respectively. DG is therefore much less susceptible to large-scale power outages caused by natural or the increasing number of man-made disasters that threaten national security [18]. DG can also postpone investments in generation, transmission and distribution as electrical power demand grows and at a large enough scale, eliminate them [19]. DG reduces transmission losses[20], which can be substantial being that the average grid losses is 6.8\% in OECD countries [21]. Elimination of these losses would result in cost savings of about 10-15\%) [22]. Other DG benefits include decreased pollution and greenhouse gas emissions [23], transmission congestion relief, increased reliability, and ancillary services such as voltage support, reactive power, and emergency back-up [18, 20, 24-26]. Important for PV DG in particular, summer heat waves that tend to increase peak loads and promote long distance power transfers are also characterized by high photovoltaic load carrying capabilities. The summer PV's effective load carrying capacity typically exceeds $60 \%$ over much of the U.S. [27]. This is a consequence of the fortunate solar irradiance-demand correlation, where most human activities tend to follow the sunlight cycle. For example, residential PV installations in the New England area have shown that approximately $60 \%$ of the total daily output from PV systems is supplied during the utility peak period when the utility system load is equal to or greater than $95 \%$ of the maximum load reached during the day [28]. Solar PV thus provides value to the grid by displacing generation from conventional units that use higher-cost fuels. At low solar electricity percentages, or penetration levels, the least efficient and most costly sources of conventional electricity can be removed. This would drive down both economic and environmental costs for the entire electrical production system.

Despite the benefits for the environment, grid reliability [29], national security, and the fact that there is an active search among utility planners to find viable alternatives to meet the uncertainly growing load in their planning regions/ compete effectively in the growing electricity market [16], most U.S. utilities have been particularly unenthusiastic about DG with intermittent renewable energy sources such as solar PV. Making changes in generation dispatch and operating practice, a conventional power system can enable PV to be part of the generation mix. Although higher penetration levels of PV generation (e.g. $>20 \%$ ) can be problematic, corrective measures such as assigning more generating units to regulating duty or installing fast-response combined-cycle generators have been available for decades [30]. A penetration level of 5\% or less enables the systems utility to track the changes and has been viewed as the upper limit for PV [31]. Currently, PV produced electricity provides much less than $1 \%$ of available energy and thus PV does not approach this upper limit [6], however, because the U.S. Utility reluctance is also due to the fact that at high penetration levels the savings offered by intermittent generations could be offset by the increase in their costs to maintain partial loads of reserves, making it uneconomical to add intermittent generations into utility systems. As an increasing number of conventional generating units are partially loaded to add load-following capability and operating reserve to the system with high percentage of PV, the overall grid efficiency can drop because of increased cycling duties and decreased efficiency caused by the partial loading of these generators, which will increase fuel consumption and maintenance costs.

The variations in the PV power that create this problem is due to i) night/day cycle, ii) yearly cycle, and iii) fluctuating cloud conditions. Variations i) and ii) will be addressed in the next section with the PV+CHP system as a whole. The seemingly more challenging problem, iii) of fluctuating cloud 
Published: J. M. Pearce, "Expanding Photovoltaic Penetration with Residential Distributed Generation from Hybrid Solar Photovoltaic + Combined Heat and Power Systems”, Energy 34, pp. 1947-1954 (2009). http://dx.doi.org/10.1016/j.energy.2009.08.012

conditions and thus rapidly changing PV power, will need to be addressed in the future, but on first approximation can be solved simply by deploying solar PV systems over a larger geographic area. For example, if a network of PV installations is dispersed throughout a $100 \mathrm{~km}^{2}$ area, the tolerable acute penetration increases to $18.1 \%$, and if the area again expands to $1000 \mathrm{~km}^{2}$, the limit is $35.8 \%$ [32]. In a review of several studies, Wan and Parsons estimate an upper acute penetration limit of PV generation of about $16 \%$ of the system load set by the worst-case cloud pattern [33]. It should be noted that in these studies the penetration level is the real time percentage not the overall percentage of PV electricity generation, which would of course be considerably less as peak sun hours are only available for a few hours each day.

\section{Electrical and Heat Requirements of Representative U.S. Single Family Residences}

The average annual electricity use per household in the U.S. is $10654 \mathrm{~kW}$-hrs [34]. This energy use, which comes to $29 \mathrm{~kW}$-hrs/day is largely driven by heating and cooling loads. The total electric load profile as with the thermally driven electric load profile varies widely among different regions in the U.S. and is largely dependent on if the residence heats with electricity or another fuel source and to the extent that cooling is provided by electric air conditioning. This large variation can be observed in Figure 1, which shows the normalized electric demand for residential homes in Columbus Ohio and Los Angeles California, the U.S. residential average and the U.S. Average for all sectors [35] throughout the year. The electrical consumption data in Fig. 1 was obtained from the average of six new homes in central Ohio with gas heating and the average for southern California [36]. Homes with gas furnaces and other gas-fired appliances would be expected to have the highest electric use in the summer because of cooling loads. In all cases shown in Figure 1 the electric demand peaks in the July-August region again due to cooling loads. Columbus was taken as a demonstrative northern-U.S. climate and solar flux. The relative change in electric demand throughout the year in Columbus is much larger than the residential average for the entire nation. The average of all sectors shows an even flatter distribution of electric demand throughout the year. Los Angeles was chosen as a second example city because the electric demand yearly distribution in Southern California very closely mirrors the national average electric demand distribution.

By looking at the energy demand and solar supply for a typical home in the U.S. a semi-quantitative analysis can be made at the viability of CHP systems helping increase the penetration level of solar PV. This correspondence for the northern U.S. can be seen in Figure 2, which shows the normalized electric demand for a typical single family residence in central Ohio, the normalized degree-days and the normalized solar flux for Columbus, $\mathrm{OH}$ throughout the year from data available from the National Solar Radiation Data Base [37]. As you can be seen in Figure 2 there is a fortunate correspondence between the solar flux (open circles) available for powering solar photovoltaic cells and the electric demand (closed circles) throughout the majority of the year. The peak in electric demand falls very near to the peak in solar flux. Thus, solar power facilities can be used to mitigate peak demand and hold down costs for current energy suppliers. There is, however, a small increase in electric demand in the middle of winter when the solar flux is lowest for Columbus as shown in Figure 2. This additional demand is due to a combination of the electrical requirements for the fans in the gas powered furnaces and the additional time people spend indoors entertaining themselves with electricity-consuming devices. This demand can be matched by increasing the size of the photovoltaic array and is often done 
Published: J. M. Pearce, "Expanding Photovoltaic Penetration with Residential Distributed Generation from Hybrid Solar Photovoltaic + Combined Heat and Power Systems", Energy 34, pp. 1947-1954 (2009). http://dx.doi.org/10.1016/j.energy.2009.08.012

on off-grid applications. In the case being analyzed here, a CHP system will supplement the electricity provided by the PV array. When the PV system is not providing enough power the CHP system will turn on and maintain a constant load. During the times of the year with less solar flux the CHP will have longer run times throughout the day. The heat generated by the CHP system will thus have a yearly distribution as one minus the solar flux. Again, there is a fortunate correspondence of the distribution throughout the year between the heat available from the CHP system and the heat needed to keep the residence warm, which is proportional to the degree-days for the region. This correspondence is shown in Figure 2, where the triangles are data sets of the normalized degree-days (closed) and one minus the solar flux (open).

The same analysis is valid at other locations with the following qualifications. First, in southern areas and hotter locations the amount of thermal energy needed for domestic hot water would decrease although still exist, and the thermal energy needed for home heating will decrease significantly or completely disappear. The $\mathrm{CHP}+\mathrm{PV}$ hybrid system will then only obtain high energy conversion efficiencies if the heat generated by the CHP device is used for cooling (i.e. to drive an absorption chiller), although thermal hot water requirements would still represent a partial sink for the waste heat. This can be seen if Figure 3, which shows the normalized electric demand for a typical single family residence in Southern California and the normalized degree-days and the normalized solar flux for Los Angeles, CA. In Los Angeles there is a similar fortunate correspondence between the solar flux and the electric demand as observed in Columbus. In Los Angeles the match is more closely followed throughout the entire year. However, the thermal energy needed to heat a residential home in Los Angeles is much less than for a similar house in Columbus (e.g. $280^{\circ} \mathrm{F}$-days in LA vs $1024^{\circ} \mathrm{F}$-days in Columbus in December). For homes in climates similar to Los Angeles a PV+CHP system that levels off electric use throughout the year is needed that can produce cooling from the heat generated by the CHP system.

On an instant time basis the demand in a given residence can fluctuate significantly [36]. T In order to obtain a basic understanding of the performance of DG equipment over a diurnal period data the hourly change in electrical demand is necessary. Using the previously considered utility residential load profile data, the data are analyzed for southern California each hour of the day across all days in the year. Figure 4 shows the average electrical use for each hour, which coincidently peaked at $1 \mathrm{~kW}$-hr per hour (thus a power) and was thus not normalized. Superimposed on the electric demand is the normalized solar flux for a typical day in the winter, the lowest solar flux scenario. The gray area represents the electrical demand that could be provided by a residential solar array. The area (energy produced) can be altered by changing the angle at which the solar cells are mounted and by adding additional panels to drive the available power at any hour of the day higher. This would result in enlarging the light grey area, which represents the time of day a residential solar array could provide excess power to the grid if it were sized to provide $1 \mathrm{~kW}$-hr per hour at its peak in the day. Regardless of how large the array is, there will always be a significant fraction of the residential load that can not be met in real time with solar electricity. This area is in black in Figure 4 and should be matched as closely as possible by the output of a CHP system if the heat is being utilized. 
Published: J. M. Pearce, "Expanding Photovoltaic Penetration with Residential Distributed Generation from Hybrid Solar Photovoltaic + Combined Heat and Power Systems", Energy 34, pp. 1947-1954 (2009). http://dx.doi.org/10.1016/j.energy.2009.08.012

\section{Design of Solar Photovoltaic and Combined Heat and Power Hybrid System}

The residential CHP system investigated here is based on a commercialized system with solar photovoltaic cells. The PV+CHP hybrid thus consists of three technologies: 1) an advanced warm air heating system and 2) a natural gas engine-generator part of the commercial cogen system, and 3) a PV array. This hybrid PV+CHP package yields synergistic benefits that surpass what each system can provide independently. The simple cogen system $\left(0^{\text {th }}\right.$ generation in Table 1$)$ is already available commercially and the $1^{\text {st }}$ generation PV+CHP hybrid will be available in 2009 [38]. Generations 2 can be fabricated using existing technologies and can be expected in the medium term.

The engine in the CHP system is controlled by an engine management computer similar to the engine management computer on modern automobile engines. It maintains appropriate air fuel ratio via oxygen sensor feedback, throttle position, and load, while monitoring 150 of the engine and generator functions overall. The furnace employs a microprocessor control board like all modern home heating furnaces which controls ignition, flame sensing, and blower operation. The commercialized residential CHP system incorporates a third microprocessor to act as a system controller, which communicates with the engine and furnace controllers and the thermostat, coordinating their operation. To improve operations and maintenance, the system controller is connected to the internet for remote monitoring, control, troubleshooting, diagnostics and service messages.

\section{4a. $0^{\text {th }}$ Generation: Base CHP System}

In the standard operation mode, when the home calls for heat the $1.2 \mathrm{kWe}$ engine-generator starts and provides waste thermal energy $(11,500 \mathrm{BTU} / \mathrm{hr})$ to heat the home while producing electricity that can be fed back onto the grid or used in the home. When it is extremely cold the furnace provides any additional needed heat. The furnace has a fixed firing rate and is available in a number of sizes to match the heating load of the house or building in the particular climate. By recycling the heat from the enginegenerator back into the heating system homeowners are able to use the heat twice, first to produce power and then to heat their homes. This heat would be needed anyway to maintain a comfortable temperature in the home. Thus, the electricity produced is essentially "free". Fortunately, this system provides better performance than standard forced air heating systems and helps counter the pervasive "environmentally friendly means going without" myth. The system provides enhanced thermal comfort during the heating season by delivering continuous, low level heat at a low flow rate to the dwelling. This approach to heating reduces temperature oscillations and the cycling normally experienced with typical home heating appliances. In the warm air version, constant operation also draws more air through the air filtration system and helps improve indoor air quality [39].

The currently commercialized CHP system has the engine and furnace at a fixed capacity. The engine has a fixed input and runs a more or less continuous RPM to maintain $1.2 \mathrm{~kW}$ electric power output. It does not load follow. Since the current CHP system cannot operate at partial load, the engine would have be stopped and started frequently depending on the cloud conditions if it was to match the PV output during the day. Future work is needed to determine the viability of this method using high resolution data for PV output in any given location. This could lead to accelerated wear of the engine and would also result in an overall small thermal energetic efficiency drop compared to operation at full 
Published: J. M. Pearce, "Expanding Photovoltaic Penetration with Residential Distributed Generation from Hybrid Solar Photovoltaic + Combined Heat and Power Systems", Energy 34, pp. 1947-1954 (2009). http://dx.doi.org/10.1016/j.energy.2009.08.012

load. In the case of using the CHP to back up the PV at night, this preliminary system can not dump heat so would cause excessive warming of the home, and is not acceptable as the CHP base for a PV+CHP hybrid system.

\section{4b. 1st Generation: PV+CHP Hybrid System}

The development of their first PV+CHP hybrid is nearly complete. This system includes all of the features of the standard CHP system and also incorporates an automatic transfer switch and sub panel enabling a backup power mode if the grid goes down. In backup power mode the system will load follow and provide up to $1.8 \mathrm{kWe}$. This system will include a two stage furnace with $95 \%$ AFUE, black start, and heat dump capabilities allowing the system to operate during a summertime grid outage. In addition, the system should allow for the application of a 600 Watt PV module with its own inverter and utilize the existing automatic transfer switch. It should be noted that the electrical energy conversion efficiency of commercially available PV panels range from $10 \%$ for some amorphous silicon thin film cells to $20 \%$ for heterojuction with intrinsic thin (HIT) layer cells made from a combination of amorphous and crystalline silicon materials.

The PV+CHP system (as seen in Figure 5) is extremely efficient when compared to the conventional electricity and heat energy supply and waste for residential home (as seen in Figure 6). As can be seen in Figure 5, in the reciprocating engine, $22 \%$ of the energy contained in the natural gas delivered to the home is converted into electricity and $62 \%$ is delivered to an advanced furnace to provide additional heating to reduce gas use [40]. Thus in total only $16 \%$ of the energy in the natural gas going to the CHP system is wasted during ideal times when all of the heat energy is used. The furnace coupled to the CHP system operates with a 93 to $95 \%$ AFUE heating efficiency and provides the combined heat and power efficiency of the CHP unit is $84 \%$ for the conversion of natural gas to useful energy. This helps lower both household energy costs and reduce environmental pollution and GHG emissions even without the PV. The addition of the PV entails an even greater addition of low GHG emission electricity. The PV panel converts approximately $20 \%$ of the sunlight that is incident on into electricity, with the remainder going to waste heat. In the conventional house all the sunlight striking the roof of the home is essentially wasted (or contributes to cooling loads). As seen in Figure 6, in the conventional system central power stations provide electricity demand for an entire region and most homes have forced air natural gas furnaces to provide domestic heating. The $84 \%$ efficiency of the $\mathrm{PV}+\mathrm{CHP}$ system can be directly compared to $\sim 35 \%$ efficiency for conventional power plants for burning the same natural gas. ${ }^{1}$ If the ensemble of PV+CHPs systems is large enough to eliminate some of the coal-fired based load the emissions reductions would be even more pronounced.

\section{4c. $2^{\text {nd }}$ Generation: PV+CHP Systems}

The major components behind PV+CHP systems are complete with the $1^{\text {st }}$ generation system, however, efficiencies can be driven higher with more advanced systems. First, in the $2^{\text {nd }}$ generation system the PV array can be expanded with appropriate improved control equipment to allow the CHP

\footnotetext{
${ }^{1}$ It should be noted that not all commercial electricity is derived from thermal electric power plants and that some conventional plants do use cogeneration and thus have higher efficiencies. This comparison, however, is valid for most of the electrical generation in the U.S.
} 
Published: J. M. Pearce, "Expanding Photovoltaic Penetration with Residential Distributed Generation from Hybrid Solar Photovoltaic + Combined Heat and Power Systems", Energy 34, pp. 1947-1954 (2009). http://dx.doi.org/10.1016/j.energy.2009.08.012

system to offer a $100 \%$ back up for the PV. In this back up mode the controls would enable load following. This would entail advanced controls and possibly a different CHP technology. Currently, the only systems available on the market at competitive costs are based on internal combustion engines, however, other technologies such as fuel cells and Stirling engines are possible candidates for the CHP supply in the near future. A power-controlled CHP plant that compensates power supply deficits of renewable energy components is ideal for minimizing the input of fossil energy carriers at high plant utilization ratio while simultaneously ensuring a self-generated supply as high as possible [41]. This system, would not be able to utilize $100 \%$ of the heat so heat dumping capabilities would be necessary and the CHP system efficiency would necessarily drop. This is sub-optimal but would allow for the maximum amount of solar electricity for complete back up by the CHP system. Such a system would provide a continuous source of $1.2 \mathrm{~kW}$ of power to the grid and/or home.

\section{4d. Future Generation: PV+CHP Systems}

In the future $\mathrm{PV}+\mathrm{CHP}$ systems can be designed to utilize a greater percentage of the heat energy available from the CHP unit, thus raising efficiencies closer to the ideal. In a $3^{\text {rd }}$ generation, in order to make up for the continued waste of some heat, an absorption chiller is added to the system to utilize the CHP produced heat for cooling. This is particularly important for the CHP system backing up the PV system on hot nights in the summer. In addition, this generation of PV+CHP technology will greatly increase the geographic range over which the systems could be deployed economically as locations with less heating degree days can take advantage of reduced load from their relatively high number of cooling degree days.

Finally in the $4^{\text {th }}$ generation PV+CHP system a second solar technology will be utilized to reduce the amount of wasted energy from the sun. A solar thermal system will be added either in addition to the PV mounted on the roof or integrated directly with them as photovoltaic thermal (PVT) devices to use solar produced heat to provide additional heating for the home for domestic hot water or space heating in the winter and cooling via the absorption chiller in the summer. Solar thermal powered air conditioning is a particularly appealing synergistic application because high insolation often occurs in the summer where demand for air conditioning is greatest. Commercially produced absorption chillers are readily available for air conditioning, requiring either steam or hot water as an input [42]; singleeffect absorption chillers operate well at input temperatures of $85^{\circ} \mathrm{C}$ and above and so are well suited to use the thermal output of the PV+CHP with a solar thermal addition.

\section{Methodology: Sizing the PV+CHP System}

The electric power and rated thermal power of $0^{\text {th }}$ generation systems comprised of simple cogeneration systems is sized to maximize its thermal output within the scope of the application in order to reduce primary energy and GHG emissions with CHP-generated electricity without wasting any of the heat generated [43]. For applications with a lower utilization of the CHP system such as space-heating purposes, Voorspools and D'haeseleer have already demonstrated that static formulas may lead to large 
Published: J. M. Pearce, “Expanding Photovoltaic Penetration with Residential Distributed Generation from Hybrid Solar Photovoltaic + Combined Heat and Power Systems", Energy 34, pp. 1947-1954 (2009). http://dx.doi.org/10.1016/j.energy.2009.08.012

errors in calculated savings when compared to the actual primary-energy savings and emission sector [44-46]. More detailed optimization schemes dimension cogeneration by maximizing the really occurring energy savings or emission reduction rather than simply maximizing its output [44-46]. These schemes need to be developed for each sector individually (e.g. residential, work place, leisure, and service sectors) [47] and must be carefully vetted for uncertainties in the design and operation of residential of the cogeneration units [48]. With careful modeling this is done by i) reducing the size of cogeneration unit whereby the rated thermal power of the cogeneration unit is diminished while the annual use is increased or ii) increasing the annual use of this cogeneration into periods of lower heat demand (and thus some heat would be lost) [49].

In the case of the PV+CHP systems the determination of proper sizing is more complex because the overall systems is made up of two separate generation units. Any analysis having multiple subsystems has many optimization parameters such as the optimization of the the absolute and relative size of the units and the actual use of the units. Doing a complete analysis of the evolution of the PV+CHP systems for different geographic and climate conditions is beyond the scope of this study and will be left for future work. A semi-quantitative analysis, however, is presented here to indicate the sizing requirements necessary for the best choices of installation sites and the ability of PV+CHP systems to increase PV penetration in the U.S.

First, the PV+CHP systems will be sized so that the CHP system can provide complete back up of the PV system to allow the maximum PV penetration (i.e. $2^{\text {nd }}$ generation and higher). This power level can be set by the power rating of the PV array under ideal peak conditions. The more advanced systems with load tracking could provide backup for the PV continuously, but in order to provide backup the CHP system that simply turns off and on $\left(0^{\text {th }}\right.$ generation) will need to run whenever the PV electric output drops below a predetermined level as the sun sets. In order to determine this level, first the amount of solar electricity produced must be defined. Practically, it is impossible to obtain a generation pattern of a single family home PV system because of constant variations of clouds. Statistically, however, it is possible to represent the overall generation from a set of PV systems representing a collection of a larger number of these units as an ensemble. The random aspects of each PV unit are smoothed out through the averaging effect [19].

For determining the amount of electricity and heat produced from $\mathrm{PV}+\mathrm{CHP}$ hybrids that provide $100 \%$ backup for the PV ( $2^{\text {nd }}$ generation and higher) the following method is used. It is first assumed that a typical daily generation pattern of fixed-array PV type is made and this pattern follows a Gaussian distribution. This daily generation pattern is assumed valid for each day of a month to construct a monthly generation pattern. This construction is based on the assumption that the weather is not changing significantly during the month. Such a generation pattern is constructed for each month of the year. These normalized insolation data sets are multiplied with a typical monthly PV generation pattern. In this way, a chronological generation pattern for an entire year can be obtained [16]. The CHPgenerated electricity is given by its power multiplied by the number of dark hours (24-s), where $\mathrm{s}$ is the number of peak sun hours at the sight. Thus, the total electric energy, $\mathrm{E}_{\mathrm{T}}$, provided by the PV+CHP system is given by:

$$
E_{T}=E_{P V}+E_{C H P}=\sum_{n=1}^{365} s_{n} \times P_{P V}+\sum_{n=1}^{365}\left(24-s_{n}\right) \times P_{C H P}
$$


Published: J. M. Pearce, "Expanding Photovoltaic Penetration with Residential Distributed Generation from Hybrid Solar Photovoltaic + Combined Heat and Power Systems", Energy 34, pp. 1947-1954 (2009). http://dx.doi.org/10.1016/j.energy.2009.08.012

where $\mathrm{E}_{\mathrm{PV}}$ and $\mathrm{E}_{\mathrm{CHP}}$ are the electricity provided per year from the PV system and the CHP system respectively. The solar electricity is given by number of peak sun hours multiplied by the power of the photovoltaic array, $\mathrm{P}_{\mathrm{PV}}$. Peak sun hours are defined as the equivalent number of hours per day, with solar irradiance equaling $1,000 \mathrm{~W} / \mathrm{m}^{2}$, that gives the same energy received from sunrise to sundown. The peak power of the CHP system is $\mathrm{P}_{\mathrm{CHP}}$. The total heat, $\mathrm{H}_{\mathrm{T}}$, provided by the CHP system in a given year is:

$$
H_{T}=\sum_{n=1}^{365} H_{C H P} \times\left(24-s_{n}\right)
$$

where $\mathrm{H}_{\mathrm{CHP}}$ is the heat provided by the CHP system per hour that it is operating per day. An idealized solar PV+CHP system would be sized to handle the largest fraction possible of the annual electricity production for a residential home. The average annual electricity use per household in the U.S. is 10,654 $\mathrm{kW}$-hrs [34]. For the $2^{\text {nd }}$ generation PV+CHP systems and beyond for any value of peak sun hours, and assuming the CHP system is run as back up for a 1.2kWp PV system, 10,512 kW-hrs are produced per year following equation (1), which compares favorably with the average electricity use of a home in the U.S. Obviously this value of consumption could be reduced via conservation measures and the fact that much of this load is due to heating and cooling so the PV+CHP system could on average be a net supply of electricity to the grid. Following equation (2), the PV+CHP systems would produce between 74 million and 96 million btu (Mbtu) per year for peak sun hours ranging from seven to two respectfully. A portion of this heat could be used to provide domestic hot water. U.S. Residential Energy Consumption Survey (RECS), average water-heating energy consumption per household ranges from 11.8 Mbtu for households earning less than $\$ 10,000$ to $19.3 \mathrm{Mbtu}$ for those earning $\$ 50,000$ or more in 2001 [50]. Thus for low income homes the hot water requirements would utilize between 12 and $16 \%$ depending on the solar flux, and 20 and $26 \%$ for wealthier households of the CHP heat production. The remaining heat would be used for home heating where appropriate. In many locations, such CHP systems would produce far too much thermal energy for a home heating needs. In the $3^{\text {rd }}$ generation of PV+CHP systems this problem is resolved as this heat will have to run an absorption chiller to maintain constant thermal comfort in the home while pushing as much PV-generated electricity on the grid as possible.

\section{Analytical Results of thhe Penetration Level: Percentage of PV-Generated Electricity}

Once either $2^{\text {nd }}$ generation PV+CHP units are deployed and heat is allowed to be discarded or $3^{\text {rd }}$ generation PV+CHP systems are deployed so no heat is lost during CHP back up of PV, the maximum percentage of PV-generated electricity can be determined for a DG system without any energy storage. As a first approximation, it can be assumed that the solar flux available follows a Gaussian distribution, as can be verified by fitting the normalized solar flux data from Fig. 4 for times (t) 0 to 24 throughout the day with a scaled Levenberg-Marquardt algorithm in any mathematical software package to the function:

$$
\frac{E(t)}{E_{\max }}=o+A \cdot \sqrt{\frac{2}{\Pi w}} e^{-2\left(\frac{(t-t c)}{w}\right)^{2}}
$$


Published: J. M. Pearce, "Expanding Photovoltaic Penetration with Residential Distributed Generation from Hybrid Solar Photovoltaic + Combined Heat and Power Systems", Energy 34, pp. 1947-1954 (2009). http://dx.doi.org/10.1016/j.energy.2009.08.012

where $\mathrm{E}$ is the amount of energy produced at time $t, \mathrm{E}_{\max }$ is the maximum amount of energy in a day, and for Fig. 4, $\mathrm{A}$ is $0.5, \mathrm{t}_{\mathrm{c}}$ is the center at 12.6 hours, $\mathrm{w}$ is 4.05 , and the offset (o) is $-1.02 \mathrm{e}^{-2}$ with an $\mathrm{R}^{2}$ of 0.98. It should be noted here that divergence from such a distribution due to cloud cover must be considered and has been discussed elsewhere[51,52]. As the solar flux is directly proportional to the energy produced by PV systems, the maximum percentage of PV generated electricity can then be found by:

$$
M_{P V}=\frac{\sum_{t=1}^{N=24}\left(\frac{E(t)}{E_{\max }}\right)}{\sum_{t=1}^{N=24} t}
$$

Using the data from Fig. 4 and equation (4) for a load demanding constant power where the normalized $\mathrm{P}_{\mathrm{PV}}+\mathrm{P}_{\mathrm{CHP}}=1$ at all times, the maximum energy the PV could supply over a day is $20 \% .^{2}$ If the PV+CHP system of the $1^{\text {st }}$ generation this percentage will be reduced by half as only half of the PV power is available. In reality the peak electrical demand does not need to be supplied all 24 hours. In fact only $69 \%$ of the energy for a 24 hour peak is necessary in Fig. 4. If the PV system is sized to utilize $100 \%$ of the solar electricity the PV energy curve must be normalized with the peak of PV matching the electrical demand. As can be seen in Fig. 4 this is at hour 12. When this is done, the entire curve must be multiplied by a scaling factor, $f$ (not shown for clarity). In this example $f=0.7$. The percentage of PV electricity can be obtained by dividing the total energy supplied by PV from integral under the electrical demand curve in Fig. 5 and is given by:

$$
P_{P V}=\frac{\sum_{t=1}^{N=24} E_{\text {demand }}(t)-\left(f \cdot \frac{E(t)}{E_{\text {max }}}\right)}{\int E_{\text {demand }}}
$$

Thus the normalized PV energy generated for each hour of the day is subtracted from the normalized electrical demand. If the PV system is sized in this fashion, $25 \%$ of the electricity demand throughout the day can be provided by PV and the remaining $75 \%$ would need to be provided by CHP. If some of the PV energy is allowed to be dumped at the solar peak the percentage of PV electricity can increase, although this scheme is found to be of only marginal use. For example, if the simple normalized PV energy generated for each hour of the day is subtracted from the normalized electrical demand, some PV energy is wasted (as can be seen by the portion of the solar flux curve extending beyond the demand curve in Fig. 4). In this case PV could supply only an additional 1\% (now 26\%) of the electricity. These results are summarized in Table 2 .

Thus $25 \%$ represents a practical upper limit for the total amount of energy able to be supplied by PV in southern California in the winter with no storage in a array where PV+CHP systems are deployed on mass scale in the U.S. if no PV energy is dumped throughout the standard day. This is an enormous improvement for a steady-state solar energy fraction over the status quo acute penetration limit of $5 \%$.

This limit imposed by the night day cycle is more important than those boundary conditions imposed on the yearly cycle. In the case of zero solar energy waste in Columbus the max percentage of

${ }^{2}$ It should be noted again this is data for the winter in S. California and a comprehensive solution for any given region will be left for future work. 
Published: J. M. Pearce, "Expanding Photovoltaic Penetration with Residential Distributed Generation from Hybrid Solar Photovoltaic + Combined Heat and Power Systems", Energy 34, pp. 1947-1954 (2009). http://dx.doi.org/10.1016/j.energy.2009.08.012

solar by the month is $47.5 \%$ and for LA it is $67 \%$, with re-normalizing factors of 0.47 and 0.78 respectively. It should be noted that this analysis is only valid for a CHP system with a response time equivalent to the fluctuations in cloud cover over an array. However, sub-hourly variations in solar radiation can be very large and sometimes sudden (+/- $80 \%$ over several seconds) and most CHP systems can not respond this fast $[51,52]$. From a technical standpoint this would demand the use of some fast-response electricity storage (e.g. battery or capacitor) to smooth these rapid fluctuations. The size of an energy storage system needed to back up a PV array would be considerably smaller when hybridized to a CHP system. Future work is necessary with better time resolved PV outputs throughout the day to quantify the sizing of storage necessary in different geographic locations and provide a more accurate upper limit based on the available CHP technologies and their response times.

\section{Conclusions}

From this preliminary work it is clear that hybridizing CHP with PV can expand the PV penetration level based on conventional centralized electric generation. This study found that a $\mathrm{PV}+\mathrm{CHP}$ hybrid system overcomes the inherent challenges of intermitancy and enables the share of solar PV to be expanded without completely depending on energy storage technologies to provide back up for PV. In the example case of southern California PV in PV+CHP hybrid could provide at least $25 \%$ of the electric load - a five fold increase over the status quo. The results show that a PV+CHP hybrid system not only has the potential to radically reduce energy waste to $15 \%$ from the status quo of $65 \%$ for thermal electrical generation, but it also enables the share of solar PV to be expanded without the use of large amounts of storage technology. Coupling storage to the PV+CHP hybrid could increase the steady state PV penetration limit further and needs to be determined by further work.

\section{References}

[1] Pearce, J. Photovoltaics - A Path to Sustainable Futures. Futures 2002;34(7):663-674.

[2] Alsema, E.A., de Wild-Scholten, M.J. Environmental Impact of Crystalline Silicon Photovoltaic Module Production. Material Research Society Symposium Proceedings, 2006; 0895-G03-03.

[3] Fthenakis, V.M., Alsema, E.A. Photovoltaics energy payback times, greenhouse gas emissions and external costs: 2004-early 2005 status. Progress in Photovoltaics: Research and Applications 2006; 14: 275-280.

[4] Pearce J., Lau, A. Net Energy Analysis For Sustainable Energy Production From Silicon Based Solar Cells. In Cambell-Howe R, editor. Proc. of American Society of Mech. Engineers Solar 2002: Sunrise on the Reliable Energy Economy, 2002.

[5] de Wild-Scholten, M.J.,Alsema, E.A.Environmental life cycle inventory of crystalline silicon photovoltaic module production. Material Research Society Symposium Proceedings, 2006. 0895-G0304.

[6] Energy Information Administration. International Energy Annual 2004, Report Released. Energy Information Administration. 2006.

[7] Pearce J. M. Using the Internet to Reduce Market Risk for Alternative Energy Sources: The Case of Large-Scale Solar Photovoltaic Production. First Monday 2005;10(8). See also:

http://www.firstmonday.org/issues/issue10 8/pearce/index.html 
Published: J. M. Pearce, “Expanding Photovoltaic Penetration with Residential Distributed Generation from Hybrid Solar Photovoltaic + Combined Heat and Power Systems", Energy 34, pp. 1947-1954 (2009). http://dx.doi.org/10.1016/j.energy.2009.08.012

[8] Pearce J. M. Catalyzing Mass Production of Solar Photovoltaic Cells Using University Driven Green Purchasing. International Journal of Sustainability in Higher Education 2006; 7(4):425 - 436.

[9] Shah, A., Torres, P., Tscharner, R., Wyrsch, N., Keppner, H. Photovoltaic technology: The case for thin-film solar cells. Science 1999; 285(5427): 692-698.

[10] Baranzini, A., Goldemberg, J., and Speck, S. A future for carbon taxes. Ecological Economics, 2000;32(3): 395-412.

[11] Rafaj, P., Kypreos, S. Internalisation of external cost in the power generation sector: Analysis with Global Multi-regional MARKAL model, Energy Policy 2007;35:828-843.

[12] Department of Energy (DOE). Grid 2030 A National Vision for Electricity's Second 100 Years. United State Department of Energy. 2003.

[13] Fairley, P. The Unruly Power Grid : Advanced mathematical modeling suggests that big blackouts are inevitable, IEEE Spectrum 2005. See also: http://www.spectrum.ieee.org/oct05/1575

[14] Coll-Mayor, D., Paget, M., Lightner, E. Future intelligent power grids: Analysis of the vision in the European Union and the United States. Energy Policy 2007;35: 2453-2465.

[15] Department of Energy (DOE). National Transmission Grid Study. US Department of Energy, Washington, DC. 2002.

[16] Lin, Y., Gross, G. Production Cost Analysis of Dispersed Generation Options in a TransmissionConstrained Load Pocket of an Interconnected System. IEEE Transactions on Energy Conversion 2004; 19(1):151-156.

[17] Perez, R., Letendre, S., Herig, C. PV and Grid Reliability: Availability of PV Power during Capacity Shortfalls. Proc. of the A. Solar Energy Society Ann. Meeting. 2001.

[18] Meyers, E.M., Hu, M.G. Clean Distributed Generation: Policy Options to Promote Clean Air and Reliability, The Electricity Journal 2001;14(1):89-98.

[19] Hoff, T. E., Wenger, H.J., Farmer, B.K. Distributed generation: An alternative to electric utility investments in system capacity, Energy Policy 1996; 24(2):137-147.

[20] Pepermans, G., Driesen,J., Haeseldonckx, D., Belmans, R., D’haeseleer, W. Distributed generation: definition, benefits and issues, Energy Policy 2005; 33:787-798.

[21] International Energy Agency. Distributed Generation in Liberalised Electricity Markets, Paris, 2002:128.

[22] Dondi, P., Bayoumi, D., Haederli, C., Julian, D., Suter, M., Network integration of distributed power generation. Journal of Power Sources 2002;106:1-9.

[23] Strachan, N., Farrell, A. Emissions from distributed vs. centralized generation: The importance of system performance. Energy Policy 2006;34:2677-2689.

[24] Bayless, C. Why gas turbines will transform electric utilities. Public Utilities Fortnightly 1994;132 (22):21-25.

[25] Zerrif., H., Dowlatabadi, H., Strachan, N. Electricity and conflict: advantages of a distributed system. The Electricity Journal 2002;15(1):55-65.

[26] Patibandla, N. Expanding Environmental and Economic Benefits with Distributed Generation/ Combined Heat and Power, Environmental Quality Management 2006;16(2):99-106.

[27] Perez, R., Seals, R. Solar Resource utility Load matching Update. NREL PV Program FY 1996 Annual Report. National Renewable Energy Laboratory: Golden, CO.1997.

[28] Bzura, J.J., The New England Electric Photovoltaic Systems Research and Demonstration Project. IEEE Transactions on Energy Conversion 1990;5(2): 284-289. 
Published: J. M. Pearce, "Expanding Photovoltaic Penetration with Residential Distributed Generation from Hybrid Solar Photovoltaic + Combined Heat and Power Systems", Energy 34, pp. 1947-1954 (2009). http://dx.doi.org/10.1016/j.energy.2009.08.012

[29] McCarthy, R.W., Ogden, J.M., Sperling, D. Assessing reliability in energy supply systems, Energy Policy 2007; 35:2151-2162.

[30] Anderson, P.M. The Effect of Photovoltaic Power Generation on Utility Operation. Final Report 1984; SAND84-7000. 1984.

[31] Chalmers, S.M., Hitt, M.M., Underhill, J.T., Anderson, P.M., Vogt, P.L., Ingersoll, R. The Effect of Photovoltaic Power Generation on Utility Operation. IEEE Transactions on Power Apparatus and Systems1985;104(3): 524-530.

[32] Jewell, W.T., Unruh, T.D. Limits on Cloud-induced Fluctuation in Photovoltaic Generation. IEEE Transactions on Energy Conversion 1990; 5(1): 8-14.

[33] Wan, Y., Parsons, B.K. Factors Relevant to Utility Integration of Intermittent Renewable

Technologies. National Renewable Energy Laboratory, 1993: NREL/TP-463-4953.

[34] Energy Information Administration (EIA). U.S. Household Electricity Report. Release date: July 14, 2005 See also: http://www.eia.doe.gov/emeu/reps/enduse/er01 us.html

[35] Department of Energy (DOE). Retail Sales of Electricity to Ultimate Customers: Total by End-Use Sector, 1993 through January 2007. Data in graph from 2006 for residential and all sectors, Table 5.1. Retail Sales of Electricity to Ultimate Customers: Total by End-Use Sector, 1993 through January 2007(Million Kilowatthours), 2007. See also:

http://www.eia.doe.gov/cneaf/electricity/epm/epmxlfile5 1.xls-

[36] NAHB Research Center, Inc., Review of Residential Electrical Energy Use Data, PATH, Washington, DC. 2001.

[37] National Solar Radiation Data Base. 2007. See also: http://rredc.nrel.gov/solar/old data/nsrdb/

[38] Climate Energy, Personal Communication. 2008.

[39] Climate Energy, FreeWatt details. 2007.

[40] U.S. EPA. Technology Adoption Plan: Residential Cogeneration, 2008. See also:

http://www.epa.gov/cppd/climatechoice/CHP\%20Tech\%20Adoption\%20Plan\%20v_4-R.pdf

[41] Sontag, R., Lange, A. Cost effectiveness of decentralized energy supply systems taking solar and wind utilization plants into account, Renewable Energy 2003;28:1865-1880.

[42] IEA. Ongoing research relevant for solar assisted air conditioning systems. Technical Report: IEA Solar Heating and Cooling Task 25: Solar-assisted air-conditioning of buildings, 2002. See also: http://www.iea-shc-task25.org/english/hps6/pdf/Task25-Subtask_C-2-final_report.pdf

[43] Haeseldonckx, D., Peeters, L., Helsen, L., D'haeseleer,W. The impact of thermal storage on the operational behaviour of residential CHP facilities and the overall $\mathrm{CO}_{2}$ emissions, Renewable and Sustainable Energy Reviews 2007;11(6):1227-1243.

[44] Voorspools, K., D'haeseleer,W. The evaluation of small co-generation for residential heating, The International Journal of Energy Research 2002;26(13):1175-1190.

[45] Voorspools, K., D'haeseleer,W. The impact of the implementation of co-generation in a given energetic context. IEEE Transactions on Energy Conversion 2003;18(1):135-141.

[46] Voorspools, K.R., D'haeseleer, W.D. Reinventing hot water? Towards optimal sizing and management of cogeneration: A case study for Belgium. Applied Thermal Engineering 2006;26:1972_1981.

[47] Perry, S., Klemeš, J. Bulatov, I. Integrating waste and renewable energy to reduce the carbon footprint of locally integrated energy sectors, Energy 2008; 33(10):1489-1497. 
Published: J. M. Pearce, "Expanding Photovoltaic Penetration with Residential Distributed Generation from Hybrid Solar Photovoltaic + Combined Heat and Power Systems", Energy 34, pp. 1947-1954 (2009). http://dx.doi.org/10.1016/j.energy.2009.08.012

[48] Houwing, M., Ajah, A.N., Heijnen, P.W., Bouwmans, I., Herder, P.M. Uncertainties in the design and operation of distributed energy resources: The case of micro-CHP systems, Energy 2008;33(10): 1518-1536.

[49] Voorspools, K., D'haeseleer,W. An evaluation method for calculating the emission-responsibility of specific electric applications, Energy Policy 2000;28(13):967-980.

[50] Department of Energy (DOE). 2001 Consumption and Expenditure Tables: Water-Heating Consumption Tables. Energy Information Administration Website, August 2004, See also: http://www.eia.doe.gov/emeu/consumption

[51] Derewonko, P. and Pearce, J.M. Optimizing Design of Household Scale Hybrid Solar Photovoltaic + Combined Heat and Power Systems for Ontario, $34^{\text {th }}$ IEEE Photovoltaic Specialists Conference (in press), 2009.

[52] Pearce, J.M. Household-Scale Cogen + Solar Photovoltaic Hybrid Systems: Effects on Penetration and Storage for Eastern Ontario, 2009 Solar Buildings Conference, (in press), 2009. 
Published: J. M. Pearce, "Expanding Photovoltaic Penetration with Residential Distributed Generation from Hybrid Solar Photovoltaic + Combined Heat and Power Systems", Energy 34, pp. 1947-1954 (2009). http://dx.doi.org/10.1016/j.energy.2009.08.012

\section{Appendix 1 Symbols and Abbreviations}

CHP: combined heat and power

DG: distributed generation

$\mathrm{E}$ : energy produced

$\mathrm{E}_{\mathrm{CHP}}$ : electricity provided per year from CHP system in hybrid

$\mathrm{E}_{\max }$ : maximum amount of energy in a day

$\mathrm{E}_{\mathrm{PV}}$ a: electricity provided per year from PV system in hybrid

GHG: greenhouse gas

$\mathrm{H}_{\mathrm{CHP}}$ : heat provided by CHP system per hour that it is operating per day

HIT : heterojuction with intrinsic thin layer photovoltaic cells

IPCC : Intergovernmental Panel on Climate Change

$\mathrm{M}_{\mathrm{PV}}$ :maximum percentage of PV generated electricity

NIMBY: 'not in my backyard'

OECD: Organization for Economic Co-operation and Development

ppmv: parts per million by volume

$\mathrm{P}_{\mathrm{CHP}}$ : peak power of CHP system

PV: photovoltaic

$\mathrm{P}_{\mathrm{PV}}$ : power of the photovoltaic array, t: time 
Published: J. M. Pearce, "Expanding Photovoltaic Penetration with Residential Distributed Generation from Hybrid Solar Photovoltaic + Combined Heat and Power Systems”, Energy 34, pp. 1947-1954 (2009). http://dx.doi.org/10.1016/j.energy.2009.08.012

\section{Figures}

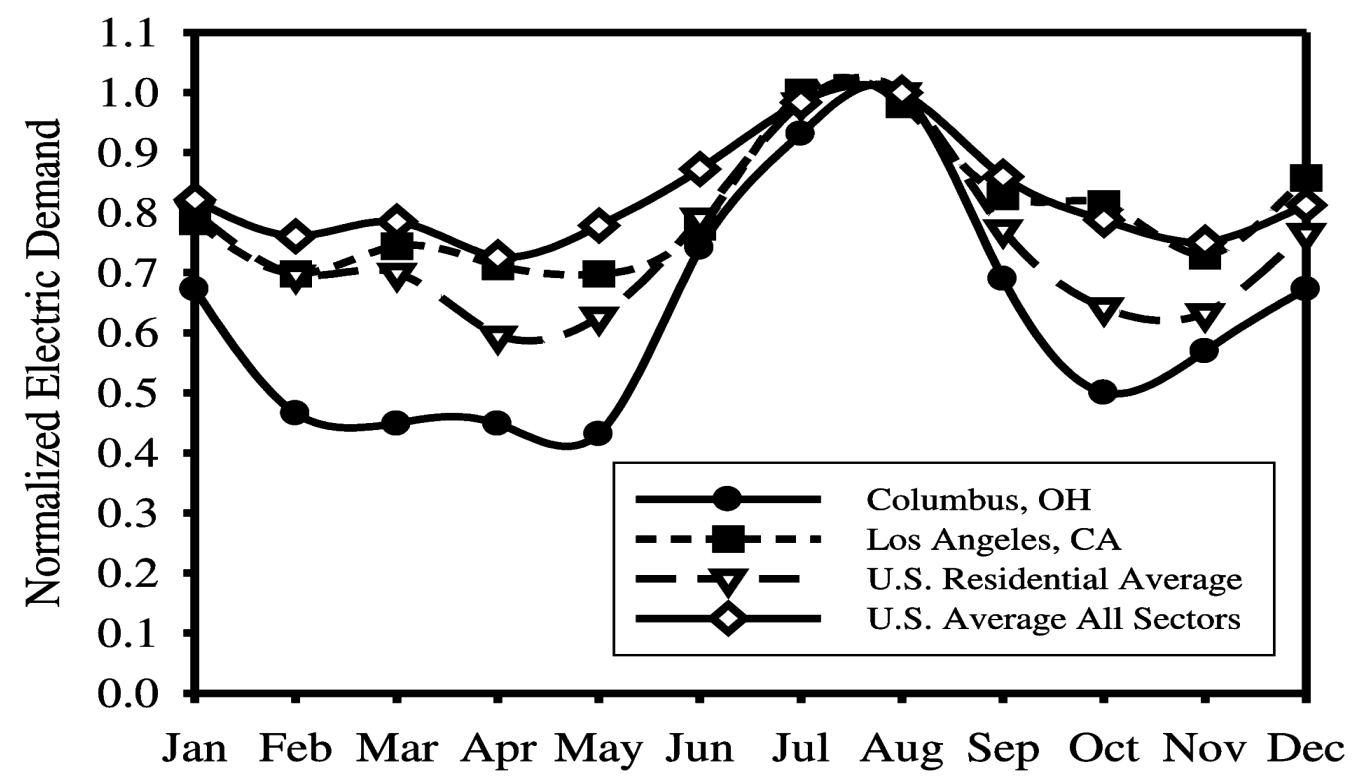

Figure 1 Normalized residential electric demand for Columbus Ohio, Los Angeles California, the U.S. residential average and the U.S. Average for all sectors throughout the year. 
Published: J. M. Pearce, "Expanding Photovoltaic Penetration with Residential Distributed Generation from Hybrid Solar Photovoltaic + Combined Heat and Power Systems”, Energy 34, pp. 1947-1954 (2009). http://dx.doi.org/10.1016/j.energy.2009.08.012

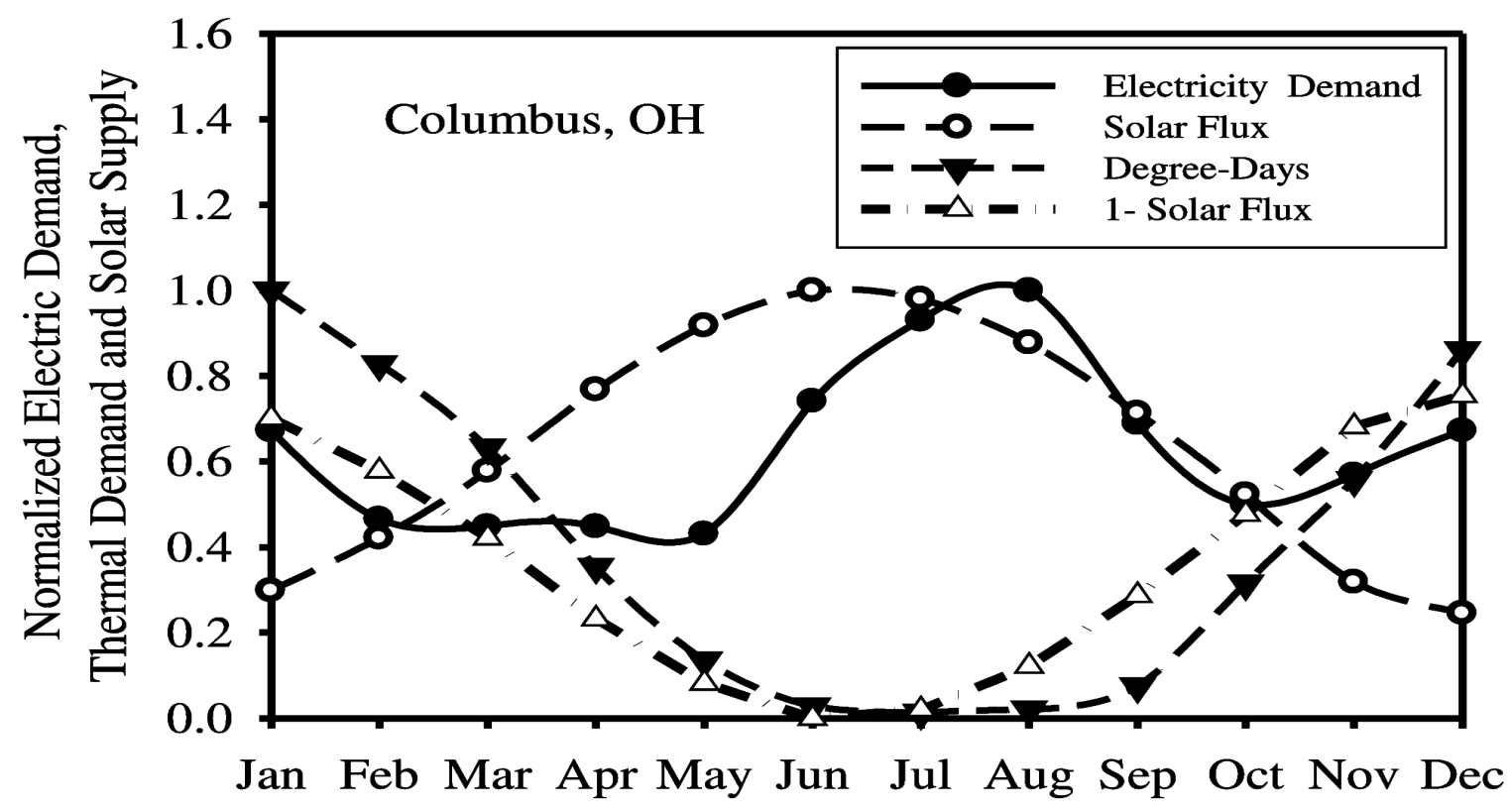

Figure 2. The normalized electric demand for a typical single family residence in central Ohio, the normalized degree-days and the normalized solar flux for Columbus $\mathrm{OH}$ throughout the year by month. 
Published: J. M. Pearce, "Expanding Photovoltaic Penetration with Residential Distributed Generation from Hybrid Solar Photovoltaic + Combined Heat and Power Systems”, Energy 34, pp. 1947-1954 (2009). http://dx.doi.org/10.1016/j.energy.2009.08.012

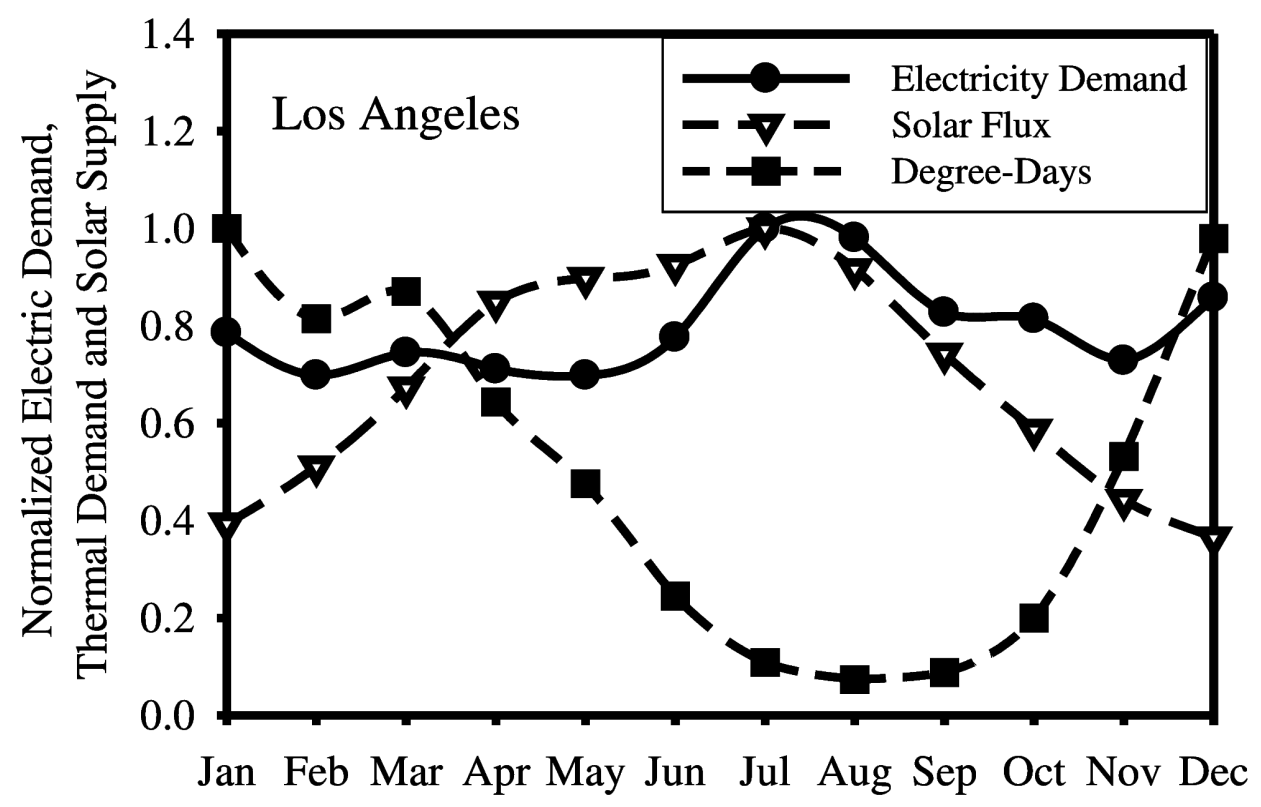

Figure 3. The normalized electric demand for a typical single family residence in Southern California, the normalized degree-days and the normalized solar flux for Los Angeles, CA throughout the year by month. 
Published: J. M. Pearce, "Expanding Photovoltaic Penetration with Residential Distributed Generation from Hybrid Solar Photovoltaic + Combined Heat and Power Systems”, Energy 34, pp. 1947-1954 (2009). http://dx.doi.org/10.1016/j.energy.2009.08.012

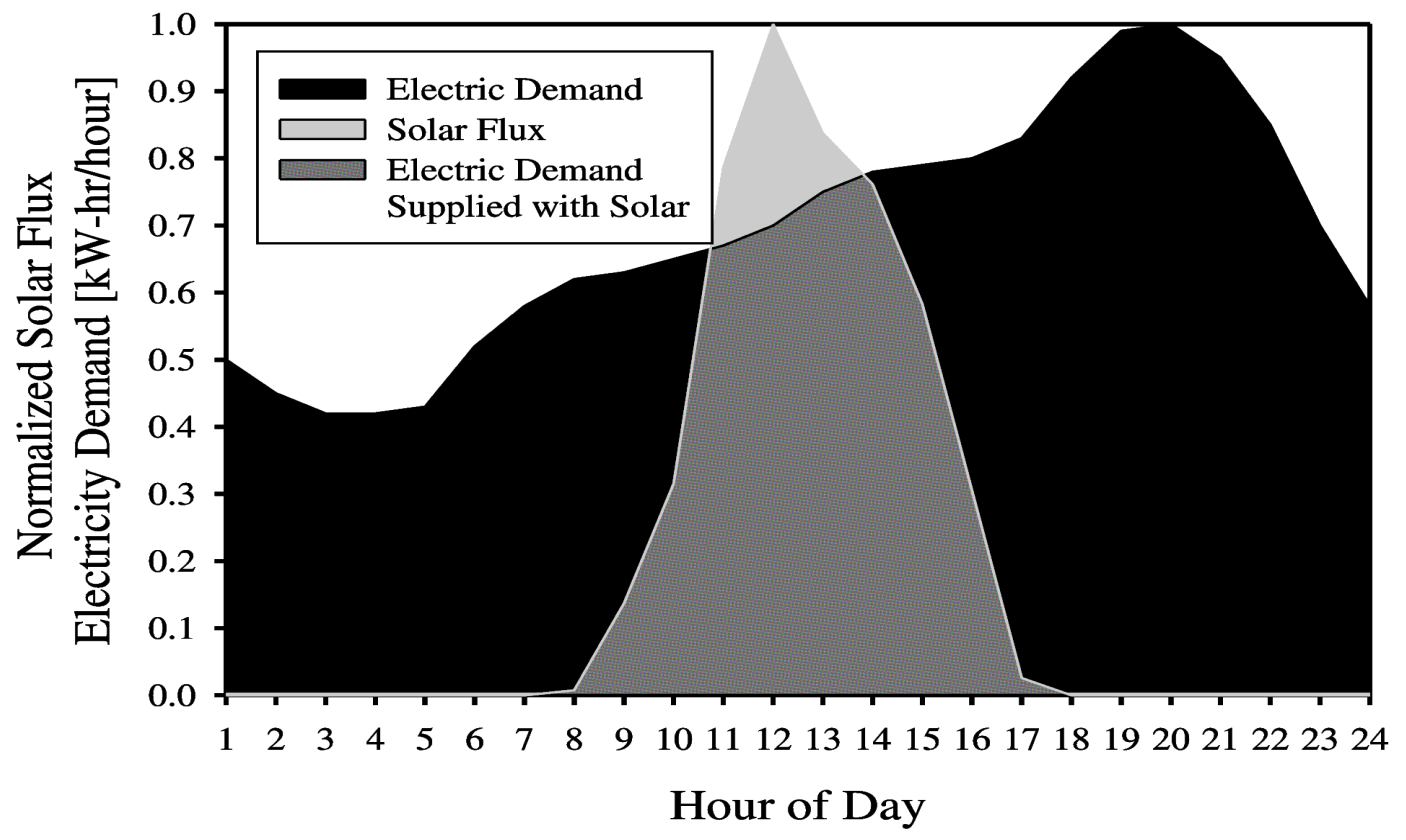

Figure 4. Normalized solar flux and electricity demand [kW-hr/hour] throughout the day. 
Published: J. M. Pearce, "Expanding Photovoltaic Penetration with Residential Distributed Generation from Hybrid Solar Photovoltaic + Combined Heat and Power Systems”, Energy 34, pp. 1947-1954 (2009). http://dx.doi.org/10.1016/j.energy.2009.08.012

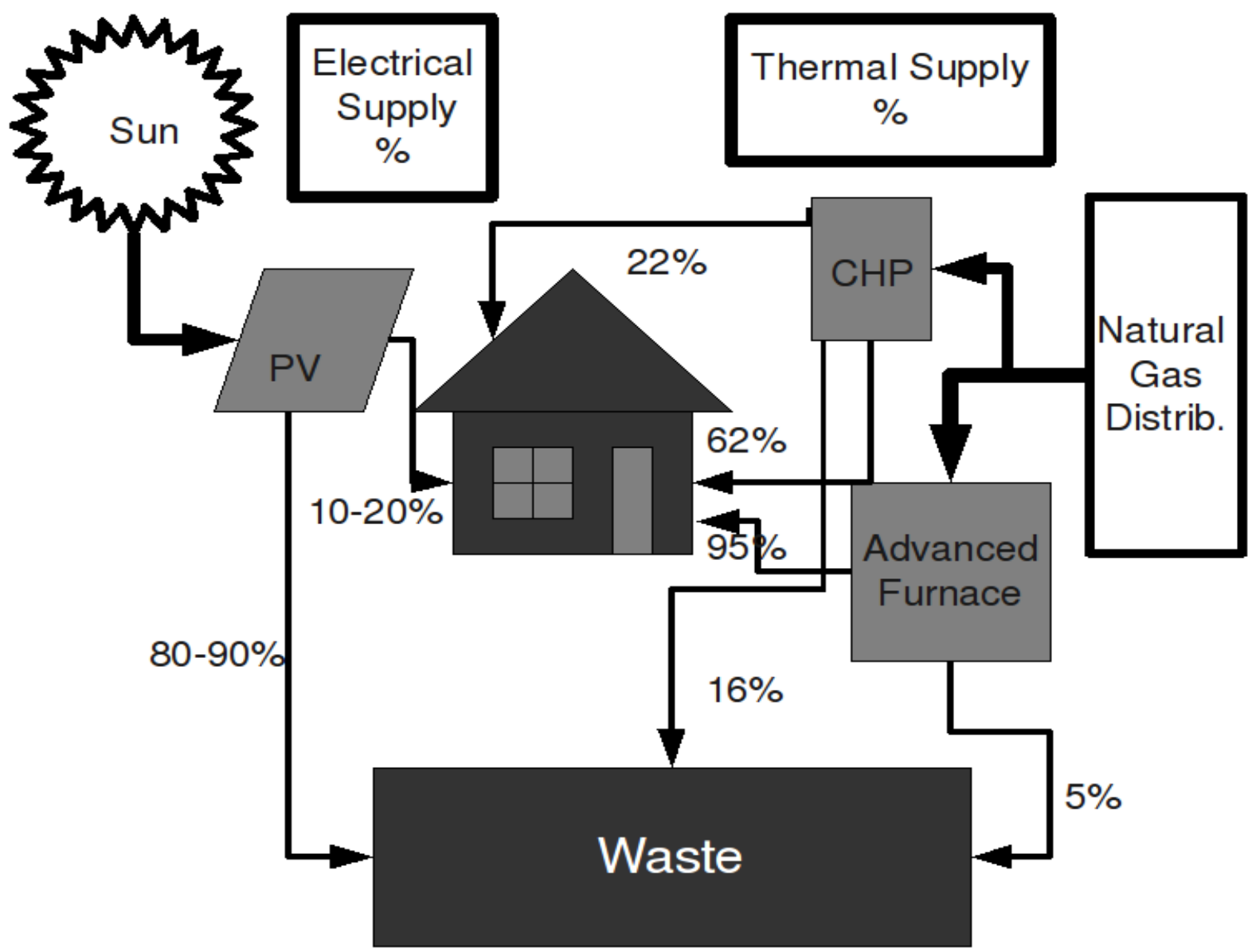

Figure 5. Electricity and heat energy supply and waste to a first generation PV+CHP residential system under optimal conditions. 
Published: J. M. Pearce, "Expanding Photovoltaic Penetration with Residential Distributed Generation from Hybrid Solar Photovoltaic + Combined Heat and Power Systems”, Energy 34, pp. 1947-1954 (2009). http://dx.doi.org/10.1016/j.energy.2009.08.012

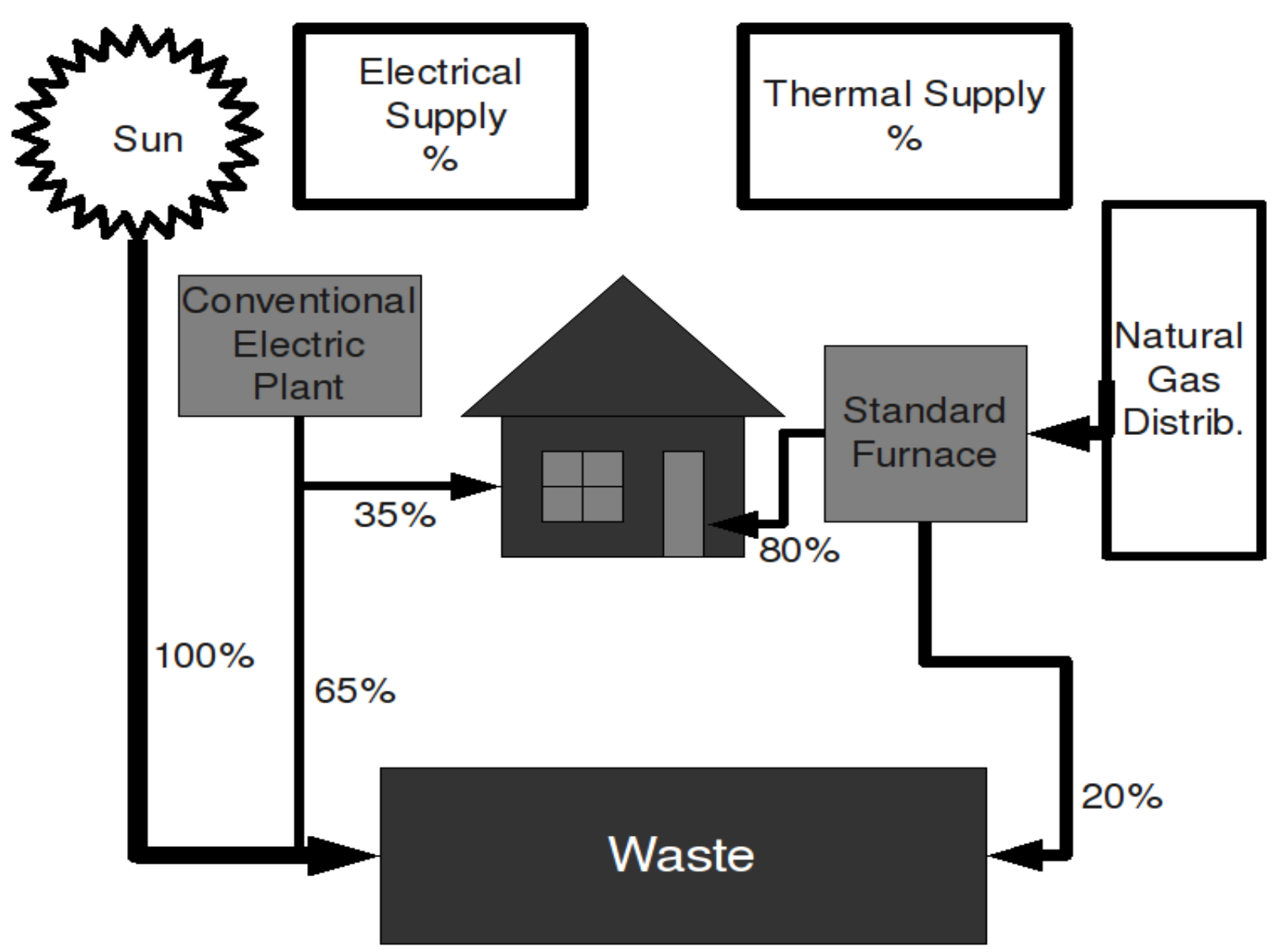

Figure 6. Conventional electricity and heat energy supply and waste for residential home under optimal conditions. 
Published: J. M. Pearce, "Expanding Photovoltaic Penetration with Residential Distributed Generation from Hybrid Solar Photovoltaic + Combined Heat and Power Systems", Energy 34, pp. 1947-1954 (2009). http://dx.doi.org/10.1016/j.energy.2009.08.012

Tables

\begin{tabular}{|c|c|c|}
\hline Generation & Systems & Capabilities \\
\hline $0^{\text {th }}$ & $\begin{array}{l}\text { Gas engine } \text { generator, } \\
\text { backup furnace }\end{array}$ & $\begin{array}{l}1.2 \mathrm{kWe} \text { CHP and advanced thermal comfort for variable thermal loads - } \\
\text { no electric load following (as seen in the right hand side of Fig. 5) }\end{array}$ \\
\hline $1^{\text {st }}$ & $\begin{array}{l}\text { Gas engine generator, } \\
\text { backup furnace, PV module }\end{array}$ & $\begin{array}{l}1.8 \mathrm{kWe}(1.2 \mathrm{kWe} \mathrm{CHP}+0.6 \mathrm{kWe} \mathrm{PV} \text { ) advanced thermal comfort for } \\
\text { variable thermal loads }- \text { fixed input for generator }- \text { heat dumping and load } \\
\text { following in backup mode (Fig. } 5 \text { where PV array is } 1 / 2 \text { power output of } \\
\text { CHP) }\end{array}$ \\
\hline $2^{\text {nd }}$ & $\begin{array}{l}\text { Gas engine generator, } \\
\text { backup furnace, PV array, } \\
\text { small electric storage }\end{array}$ & $\begin{array}{l}2.4 \mathrm{kWe}(1.2 \mathrm{kWe} \mathrm{CHP}+1.2 \mathrm{kWe} \mathrm{PV}) \text {, complete night time backup of PV, } \\
\text { advanced thermal comfort for variable thermal loads - fixed input for } \\
\text { generator - heat dumping and load following in backup mode (Fig. } 5 \\
\text { where PV array power is equivalent to CHP power) }\end{array}$ \\
\hline
\end{tabular}


Published: J. M. Pearce, "Expanding Photovoltaic Penetration with Residential Distributed Generation from Hybrid Solar Photovoltaic + Combined Heat and Power Systems", Energy 34, pp. 1947-1954 (2009). http://dx.doi.org/10.1016/j.energy.2009.08.012

\begin{tabular}{|l|c|}
\hline System & PV Penetration Level \\
\hline Standard Grid & $5 \%$ \\
\hline $1^{\text {st }}$ Generation PV+CHP & $10 \%$ \\
\hline $2^{\text {nd }}$ Generation PV+CHP (daily average) & $20 \%$ \\
\hline $2^{\text {nd }}$ Generation PV+CHP (electric demand) & $25 \%$ \\
\hline $2^{\text {nd }}$ Generation PV+CHP (electric demand, PV dump) & $26 \%$ \\
\hline $\begin{array}{l}\text { Table 2. Summary of PV penetration levels for southern California } \\
\text { example using PV+CHP hybrid systems with no electrical storage }\end{array}$ \\
\hline
\end{tabular}

